\title{
STRUCTURE AND CONSTRUCTION ASSESSMENT OF THE SURFACE LAYER OF HARDFACED COATING AFTER FRICTION
}

\author{
Krzysztof Dziedzic' ${ }^{1}$, Michał Pashechko², Marcin Barszcz', Jerzy Józwik ${ }^{3}$
}

1 Lublin University of Technology, Electrical Engineering and Computer Science Faculty, Institute of Computer Science, 36B Nadbystrzycka Str., 20-618 Lublin, Poland, e-mail: k.dziedzic@pollub.pl, m.barszcz@pollub.pl

2 Lublin University of Technology, Fundamentals of Technology Faculty, Department of Fundamental of Technology, 38 Nadbystrzycka Str., 20-618 Lublin, Poland, e-mail: mpashechko@hotmail.com

${ }^{3}$ Lublin University of Technology, Mechanical Engineering Faculty, Department of Production Engineering, 36 Nadbystrzycka Str., 20-618 Lublin, Poland, e-mail: j.jozwik@pollub.pl

Received: 2017.05.15

Accepted: 2017.08.01

Published: 2017.09.03

\begin{abstract}
The paper presents an analysis of the surface layer of Fe-Mn-C-B-Si-Ni-Cr alloy coating after friction with $\mathrm{C} 45$ steel. The coatings were obtained by arc welding (GMA). Flux-cored wires were used as a welding material. The flux-cored wires had a diameter of $2.4 \mathrm{~mm}$. The tribological assessment was performed with the Amsler tribotester under dry friction conditions at unit pressures $10 \mathrm{MPa}$. The use of XPS spectroscopy allowed deep profile analysis of the surface layer. Based on the obtained results developed model of the surface layer for friction couple, hardfaced coating obtained from Fe-Mn-C-B-Si-Ni-Cr alloy - C45 steel. It was observed that the operational surface layer (OSL) of hardfaced coatings contained oxides $\left(\mathrm{B}_{2} \mathrm{O}_{3}, \mathrm{SiO}_{2}, \mathrm{NiO}, \mathrm{Cr}_{2} \mathrm{O}_{3}, \mathrm{FeO}\right.$, $\left.\mathrm{Fe}_{3} \mathrm{O}_{4}, \mathrm{Fe}_{2} \mathrm{O}_{3}\right)$, carbides $\left(\mathrm{Fe}_{3} \mathrm{C}, \mathrm{Cr}_{7} \mathrm{C}_{3}\right)$ and borides $\left(\mathrm{FeB}, \mathrm{Fe}_{2} \mathrm{~B}\right)$.
\end{abstract}

Keywords: coatings, hardfacing, surface layer, wear, structure.

\section{INTRODUCTION}

Development of new materials is frequently focused on increasing their mechanical, tribological and corrosion and wear-resistance characteristics $[1 \div 6]$. Recently, surface modification of engineering materials has become a fast developing field of materials science. One of the most frequently used methods of regenerating machine parts is pad welding, or applying a layer of liquid metal on the regenerated object $[7 \div 9]$. The currently used materials are obtained on the basis of $\mathrm{Fe}, \mathrm{Ni}, \mathrm{Co}$, Ti with additions of various chemical elements, including: Si, Cr, B, Mn, V, Ti, Mo, W, $\mathrm{Nb}$ affecting their mechanical, tribological and corrosive properties $[10 \div 14]$. At the time of friction, the surface layer of materials used for friction couples is subject to continuous change due to external forces such as unit pressure, movement speed, temperature, environment, etc. $[4 \div 6]$. An important part of tribological studies is to understand the structure of the surface layer and changes observed during friction. A feedback effect can be observed between the friction structure and properties of the surface layer. Tests conducted on friction surfaces must accurately determine the nature of all relevant information necessary for a surface analysis which aims to help enquirers understand tribological mechanisms, and thus improve the friction process while reducing wear on the machine elements $[15 \div 19]$.

Currently, there is a distinction between technological and operational surface layers. A technological surface layer (TSL) is defined as a surface layer created as a result of deliberate actions in the course of technological processes, such as hardfacing. Its properties depend, among other things, on the technology used in the manufac- 


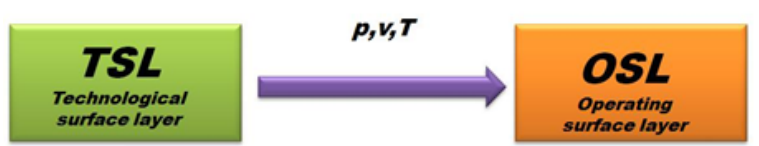

Fig. 1. Transformation of the surface layer

ture and the type of material. The concept of an operating surface layer (OSL) is defined as the condition of the layer after its exploitation. During exploitation, OSL (Fig. 1) is subject to changes due to various types of forces. It is formed during operation of a friction pair with or without the use of lubricants $[20 \div 21]$.

Different models of surface layers that we know today differ from each other mainly in the degree of detail. An indicative fact is that their creators assume a zone-based construction. The difference between the actual OSL and the theoretical model consists in the fact that certain zones do not exist or do not interpenetrate in the actual layer $[1,22 \div 23]$.

It was also observed that, in many cases, the field of machine construction and operation has shifted from examining the reliability of machines at the macro level to a comprehensive approach at the level of mechanisms employed during processes that destroy the materials used for kinematic pairs of various machines. Contemporary methods of characterization enable (microscopic) imaging and (spectroscopic) analysis of the surface of materials used for friction couples. One of the most useful techniques of depth profiling, that makes it possible to identify different elements that exist within a sample and analyse their bonds, is the X-ray photoelectron spectroscopy (XPS). Binding energy values of characteristic photoelectron peaks are tabulated. This makes it possible to conduct quantitative and qualitative analyses of chemical composition of the surface layer. The advantage of this method is the possibility of detecting chemical elements having an atomic number

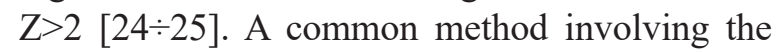
use of a scanning electron microscope and an energy dispersive X-Ray spectrometer (SEM/EDS) allows detection and identification of chemical elements having an atomic number $\mathrm{Z}>6$. Therefore, identification of the chemical composition of a surface layer which consists of elements such as $\mathrm{B}$ and $\mathrm{C}$ can be burdened with error [19].

\section{EXPERIMENTAL DETAILS}

The alloy Fe-Mn-C-B-Si-Ni-Cr was used as a core mixture for the production of flux-cored wires $2.4 \mathrm{~mm}$ in diameter. The filling percentage of the metal tape is from $30 \%$ to $35 \%$. The coating was produced using GMA welding (MAG $\mathrm{CO}_{2}$ shielding). The thickness of the padding weld was 4-5 $\mathrm{mm}$. The composition of the coating is shown in Table 1. The hardness of the coating is $49 \mathrm{HRC}$.

Tribometer was used for tribological examination. The basic parameters characterising the friction node were as follows:

- type of contact: distributed, flat (in a pin-on disc system),

- the connection of pin-on disc friction pair is created by a rotating disc and sample being pressed onto it (sample shape: 10x10 mm square, disc diameter $90 \mathrm{~mm}$, hardness 52 HRC, material: steel C45,

- type of movement: sliding friction (velocity $0.4 \mathrm{~m} / \mathrm{s}$ ),

- unit pressure: $10 \mathrm{MPa}$,

- duration of a single tribological test: 6 hours. A scanning electron microscope FEI Quanta 3D FEG was used for the examination of topography of the friction surface. The images of the wear scar were recorded in a High Vacuum mode (pressure $<6 \cdot 10^{-4} \mathrm{~Pa}$ ) with $30 \mathrm{kV}$.

The use of XPS spectroscopy allowed deep profile analysis of the surface layer (change of elements' proportions towards the inside of the material) for much bigger areas of the alloy [26]. A multi-chamber analytical system UHV by Prevac was used for the examination. Configuration of the UHV analytical system enables examination of the chemical state and composition of nearsurface layers in high vacuum conditions. The obtained data come from a sample layer made up to several atom layers, which enables the control of even subtle changes of the texture and chemical

Table 1. Chemical composition of Fe-Mn-C-B-Si-Ni-Cr coating

\begin{tabular}{|c|c|c|c|c|c|c|c|}
\hline & \multicolumn{7}{|c|}{ Element (wt.\%) } \\
\cline { 2 - 9 } & $\mathrm{Mn}$ & $\mathrm{C}$ & $\mathrm{B}$ & $\mathrm{Si}$ & $\mathrm{Ni}$ & $\mathrm{Cr}$ & $\mathrm{Fe}$ \\
\hline Coating & 7,29 & 1,63 & 1,79 & 2,46 & 17,68 & 16,24 & residue \\
\hline
\end{tabular}




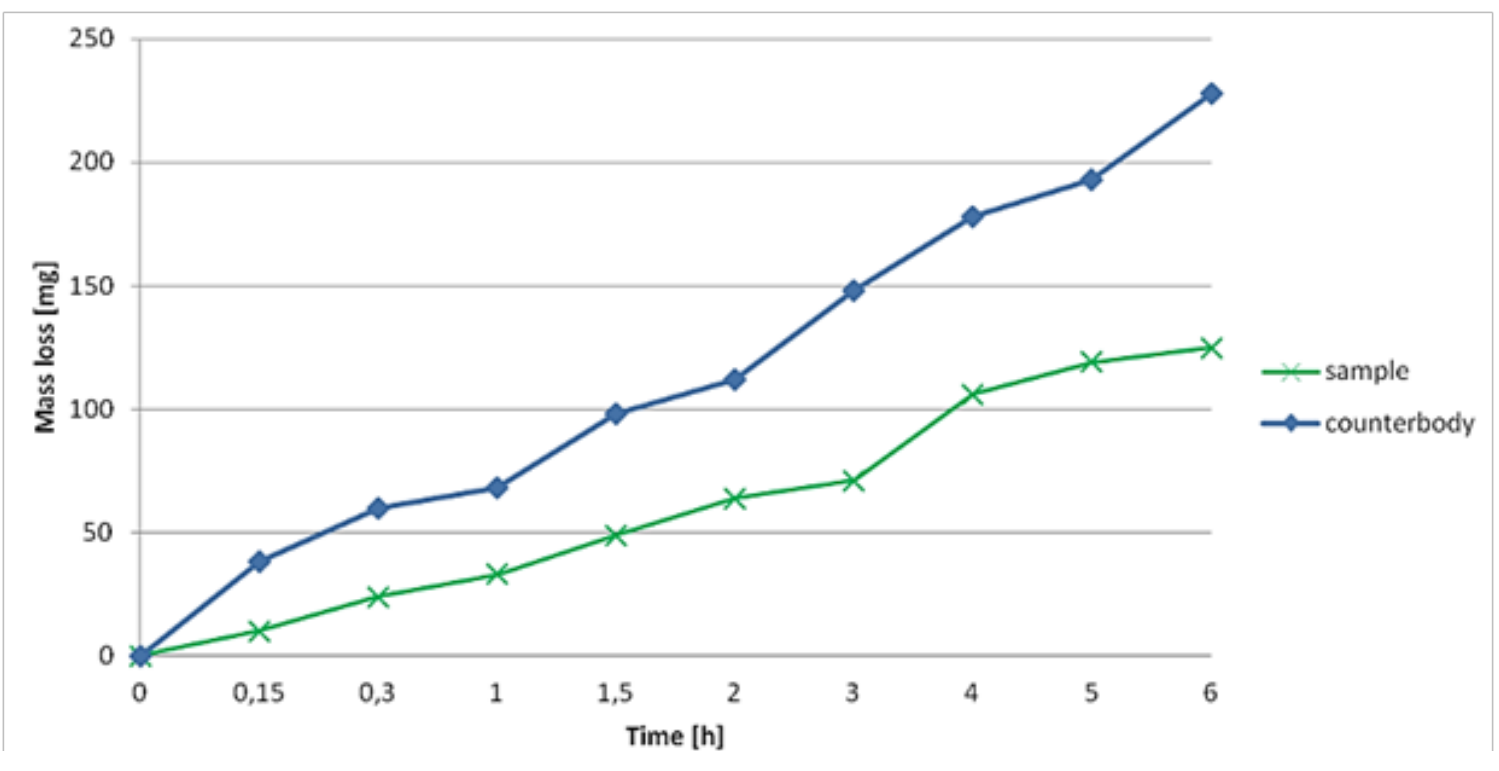

Fig. 2. Mass loss of coating (sample) and counterbody

nature of the surface of the analysed materials. The samples were cut out using an electro-erosion method and then cleansed with acetone. The sample size was $10 \times 10 \times 2 \mathrm{~mm}$. The sample was then exposed to monochromatic X-ray emitted by an MX-650 Gammadata Scienta lamp with an Al anode. The spectroscopy chamber enabled analysis with the resolution $<1 \mathrm{meV}$. The base pressure in the chamber during the measurement was $4 \times \mathrm{E}^{-9}$ mbar or higher. Consecutive surface layers were removed via etching with argon ions $\mathrm{Ar}^{+}$and XPS analysis was conducted upon each of them. The spectra were recorded from ca. $2 \times 5 \mathrm{~mm}$ area. In this way the following layers were analysed: the surface and depths of 5, 10, 15, 20, 50, 100, 200 and $600 \mathrm{~nm}$. The sputtering velocity was calculated from the following equation:

$$
\frac{z}{t}=\frac{M}{r N_{A} e} \times S j_{p}
$$

where: $\mathrm{z} / \mathrm{t}$ - sputtering velocity, $\mathrm{M}$ - molecular mass, $\mathrm{r}$ - density of the material, $\mathrm{N}_{\mathrm{A}}$ - Avogadro's constant, e - electron charge, $\mathrm{S}$ sputtering efficiency, $\mathrm{j}_{\mathrm{p}}$ - density of the ion current

The chemical composition was determined by identification and measurement of the intensity of spectra lines in the XPS spectra [21].

\section{RESULTS AND DISCUSSION}

The average mass loss of samples after tribological tests with a $10 \mathrm{MPa}$ unitary pressure and examination time of 6 hours was $125 \mathrm{mg}$. The mass loss of coating and counterbody presents Figure 2. At the same time, the average mass loss of counterbodies was $228 \mathrm{mg}$. The average wear coefficient was 0.59 .

The SEM view of the coating surface after friction is shown in Figure 3. The surface after friction has a "flake-layer" composition. Numerous wear traces are visible on the surface.

Quantitative and qualitative analyses of chemical composition of the surface layer of coatings obtained from $\mathrm{Fe}-\mathrm{Mn}-\mathrm{C}-\mathrm{B}-\mathrm{Si}-\mathrm{Ni}-\mathrm{Cr}$ alloy after tribological studies were made with the use of

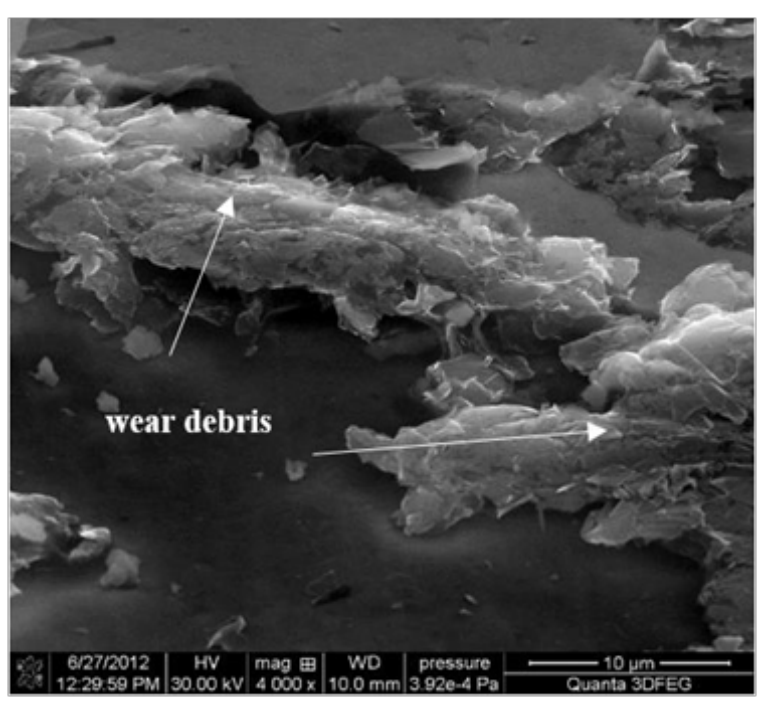

Fig. 3. Surface view of eutectic alloy coating after friction (magnification $\times 4000)$ 

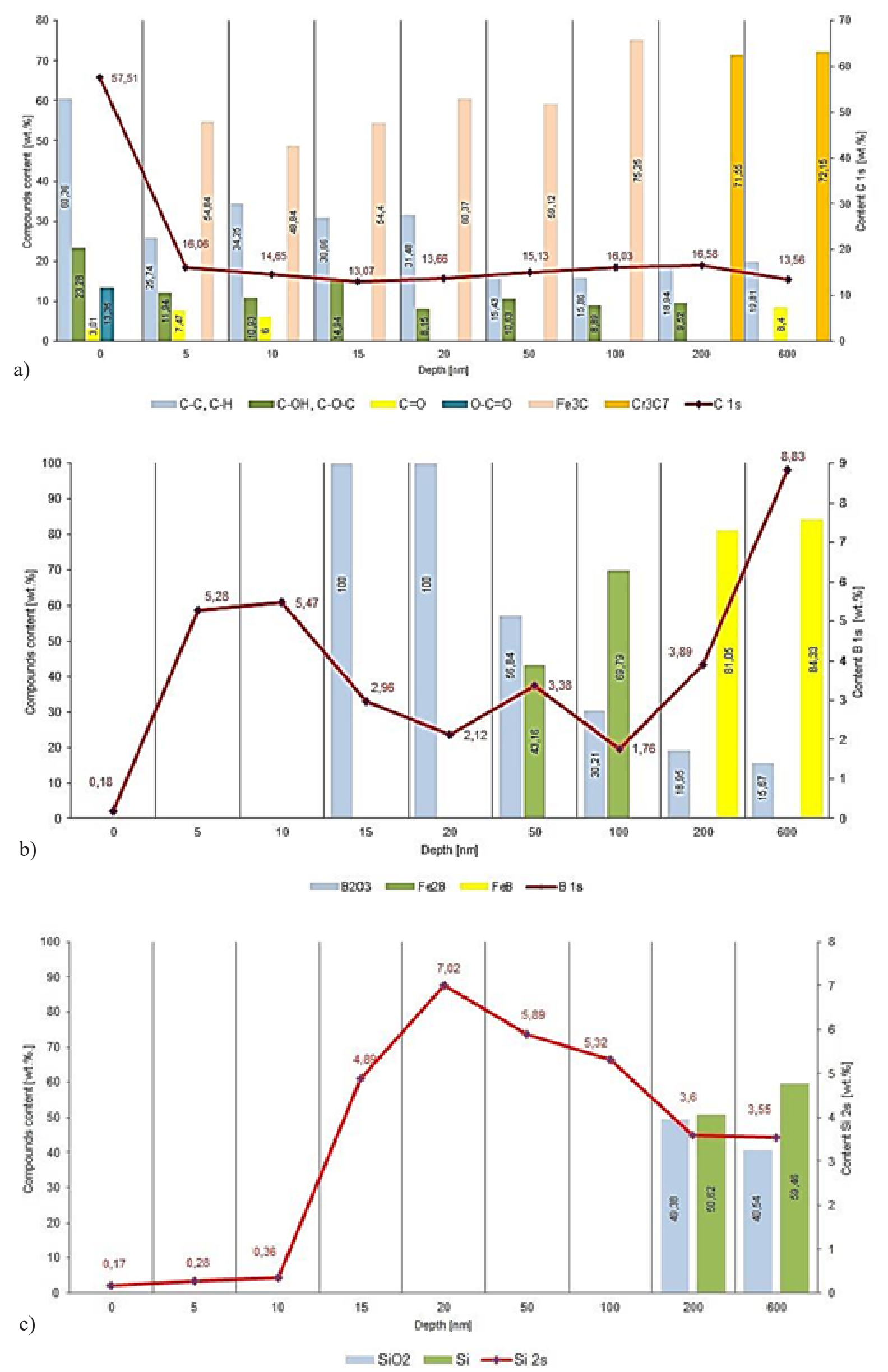

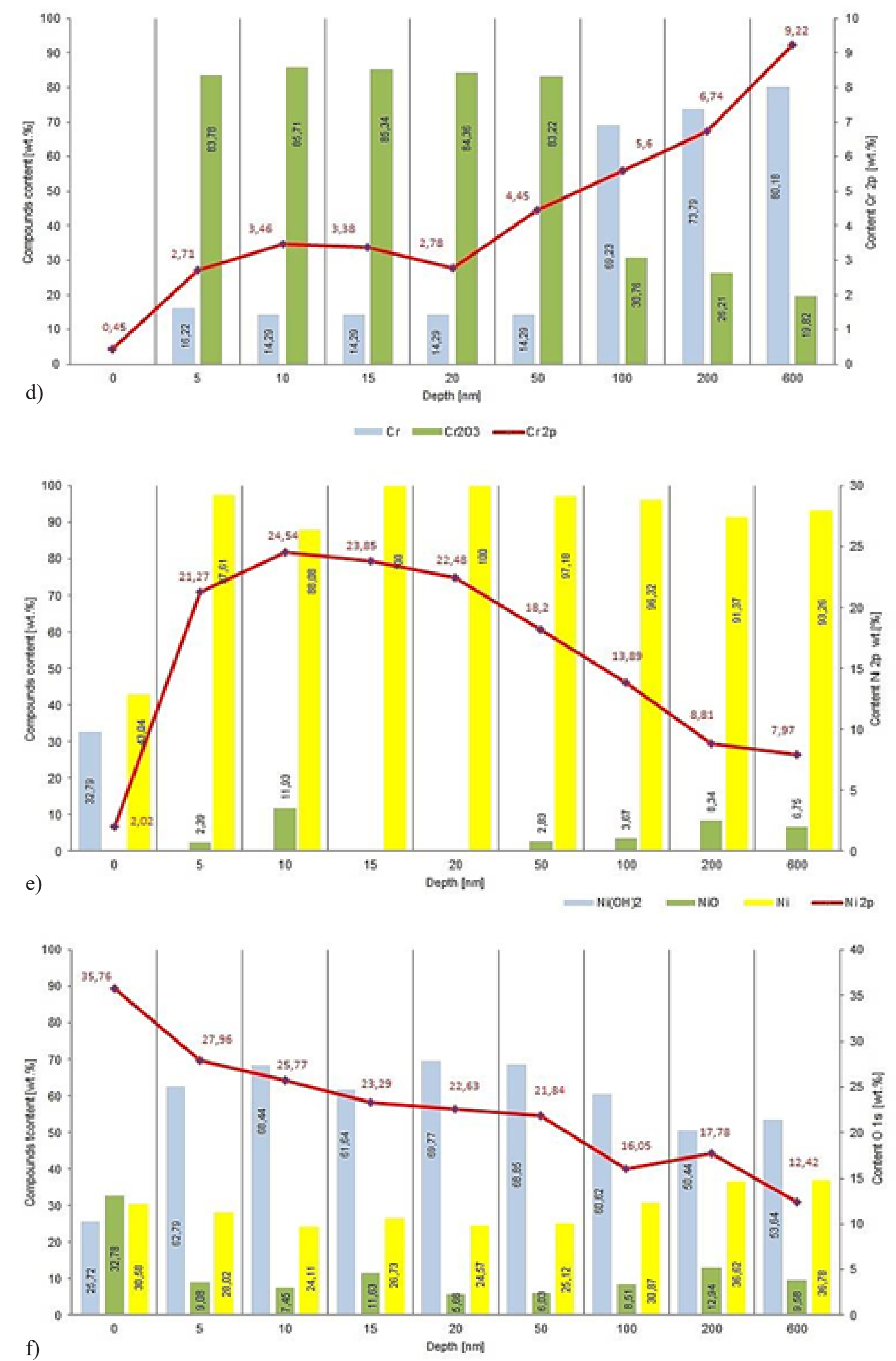


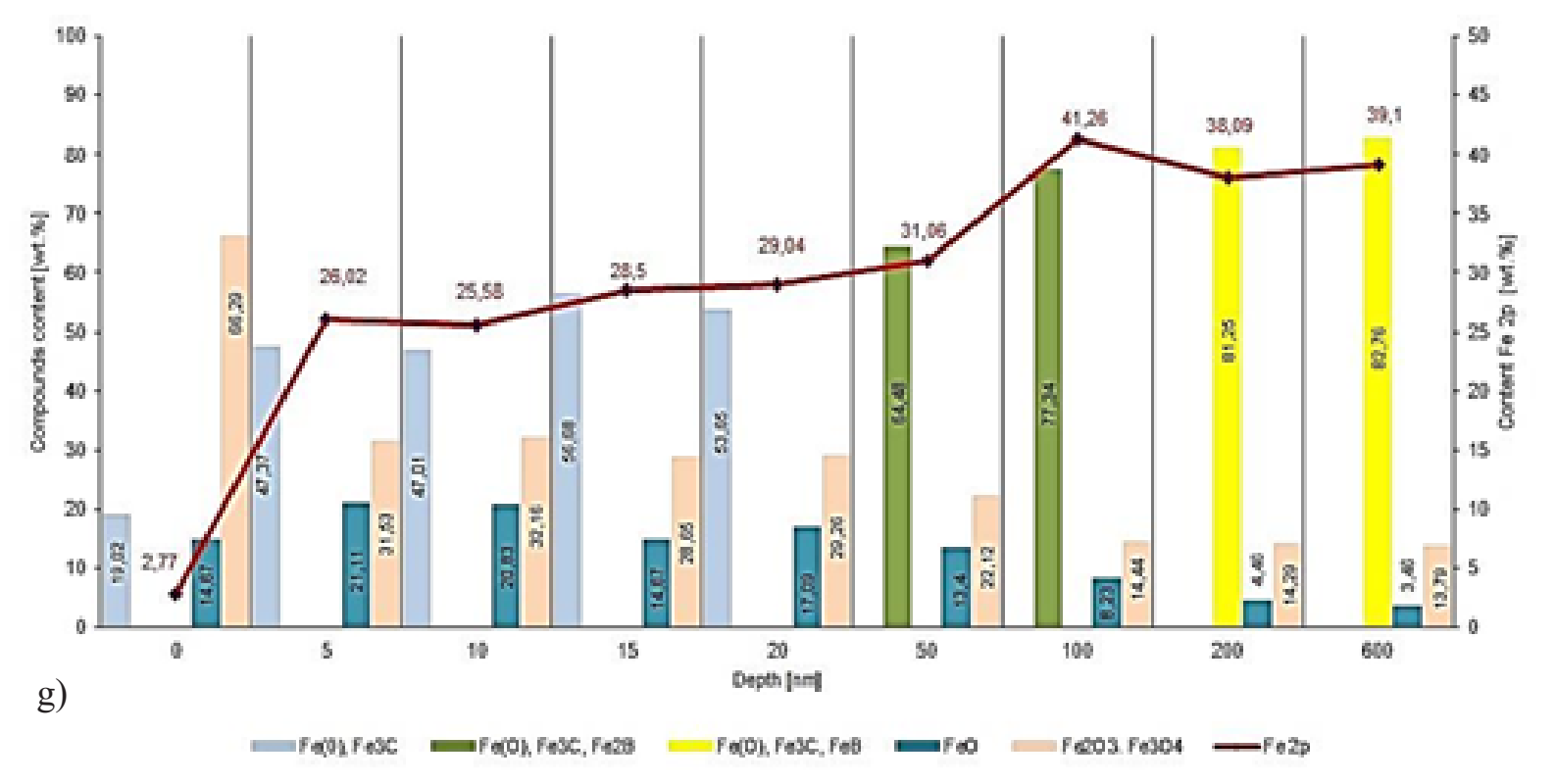

Fig. 4. Distribution of elements and chemical compounds in hardfaced coating after tribological tests: a) C, b) B, c) $\mathrm{Si}$, d) $\mathrm{Cr}$, e) $\mathrm{Ni}$, f) $\mathrm{O}, \mathrm{g}$ ) $\mathrm{Fe}$

the XPS technique. The interpenetrating surfaces of the friction couple were protected by oxygen, carbon, chromium, boron and silicon compounds. The presence of compounds such as oxides $\left(\mathrm{B}_{2} \mathrm{O}_{3}\right.$, $\mathrm{SiO}_{2}, \mathrm{NiO}, \mathrm{Cr}_{2} \mathrm{O}_{3}, \mathrm{FeO}, \mathrm{Fe}_{3} \mathrm{O}_{4}, \mathrm{Fe}_{2} \mathrm{O}_{3}$ ), carbides $\left(\mathrm{Fe}_{3} \mathrm{C}, \mathrm{Cr}_{7} \mathrm{C}_{3}\right)$ and borides $\left(\mathrm{FeB}, \mathrm{Fe}_{2} \mathrm{~B}\right)$ was observed on the basis of the characteristic energy of bonds present on the surface layer of Fe-Mn$\mathrm{C}-\mathrm{B}-\mathrm{Si}-\mathrm{Ni}-\mathrm{Cr}$ coating. The content of carbon $\mathrm{C}$ $1 \mathrm{~s}$ was the highest on the surface $(57.51 \%$ at.). Its content decreased with increasing depth. The increased amount of $\mathrm{C}-\mathrm{C}, \mathrm{C}-\mathrm{H}, \mathrm{C}-\mathrm{OH}, \mathrm{C}=\mathrm{O}, \mathrm{C}-$ $\mathrm{O}-\mathrm{C}, \mathrm{O}-\mathrm{C}=\mathrm{O}$ carbon compounds was observed on the surface and in the surface friction layer. The content of $\mathrm{Fe}_{3} \mathrm{C}$ and $\mathrm{Cr}_{7} \mathrm{C}_{3}$ (Fig. 4a) increased with depth. The content of boron B 1s was the highest at a depth of $5-10 \mathrm{~nm}(5.47 \%$ at. $)$ and $600 \mathrm{~nm}(8.83 \%$ at.). The number of boron atoms was higher in the coating after friction (Fig. 4b). Boron in the form of a $\mathrm{B}_{2} \mathrm{O}_{3}$ compound occurred at a depth of approximately $50 \mathrm{~nm}$. Along with increasing depth the content of $\mathrm{B}_{2} \mathrm{O}_{3}$ decreased, while the content of $\mathrm{FeB}$ and $\mathrm{Fe}_{2} \mathrm{~B}$ increased. The content of Si $2 \mathrm{~s}$ was the highest at a depth of $20 \mathrm{~nm}$ and amounted to $7.02 \%$ at. (Fig. 4c). Silicon in the form of a $\mathrm{SiO}_{2}$ compound occurred at a depth of approximately $200 \mathrm{~nm}$. Along with increasing depth the content of $\mathrm{SiO}_{2}$ decreased, while the content of $\mathrm{Si} 2 \mathrm{~s}$ increased. The content of $\mathrm{Cr} 2 p$ chromium in OSL after friction was lower than in the coating (Fig. 4d). Chromium in the form of a $\mathrm{Cr}_{2} \mathrm{O}_{3}$ compound occurred at a depth of approximately $50 \mathrm{~nm}$. At depths of more than $50 \mathrm{~nm}$, it was observed mainly in the form of a metallic chromium. Nickel occurred mainly in a metallic form and as $\mathrm{NiO}$ (Fig. 4e). In contrast, oxygen $\mathrm{O} 1 \mathrm{~s}$ was predominantly observed in the form of metal oxides and in $\mathrm{C}-\mathrm{OH}, \mathrm{C}=\mathrm{O}, \mathrm{C}-\mathrm{O}-\mathrm{C}$, $\mathrm{O}-\mathrm{C}=\mathrm{O}$ groups (Fig. 4f). Iron $\mathrm{Fe} 2 \mathrm{p}$ was mainly observed in a metallic form or as $\mathrm{FeO}, \mathrm{Fe}_{3} \mathrm{O}_{4}$, $\mathrm{Fe}_{2} \mathrm{O}_{3}$ and $\mathrm{Fe}_{3} \mathrm{C}, \mathrm{FeB}, \mathrm{Fe}_{2} \mathrm{~B}$ compounds (Fig. 4g).

An increased content of carbon and oxygen was detected on the surface of the counterspecimen made of $\mathrm{C} 45$ steel. It decreased with increasing depth. The content of iron, on the other hand, increased. The operational surface layer of the counterspecimen contained mainly iron oxides and chromium oxide $\left(\mathrm{Cr}_{2} \mathrm{O}_{3}\right)$. Carbon was detected in the form of $\mathrm{Fe}_{3} \mathrm{C}$, and $\mathrm{C}-\mathrm{C}, \mathrm{C}-\mathrm{H}$, $\mathrm{C}-\mathrm{OH}, \mathrm{C}-\mathrm{O}-\mathrm{C}, \mathrm{C}=\mathrm{O},-\mathrm{CO}_{3}$ compounds. Silicon was detected at depths ranging from 20 to $50 \mathrm{~nm}$ (maximum $-1.36 \%$ at.).

In the work [13] the results of studies of FeMn-C-B-Si-Ni-Cr alloys analyzed in other conditions were presented. They also were used to develop the model of the operating surface layer.

The following generalized OSL model (shown in Figure 5) was proposed on the basis of the obtained results and literature data. The chemical composition of the operational surface layer varied with depth. Deeper layers were generally characterized by the presence of less complex 


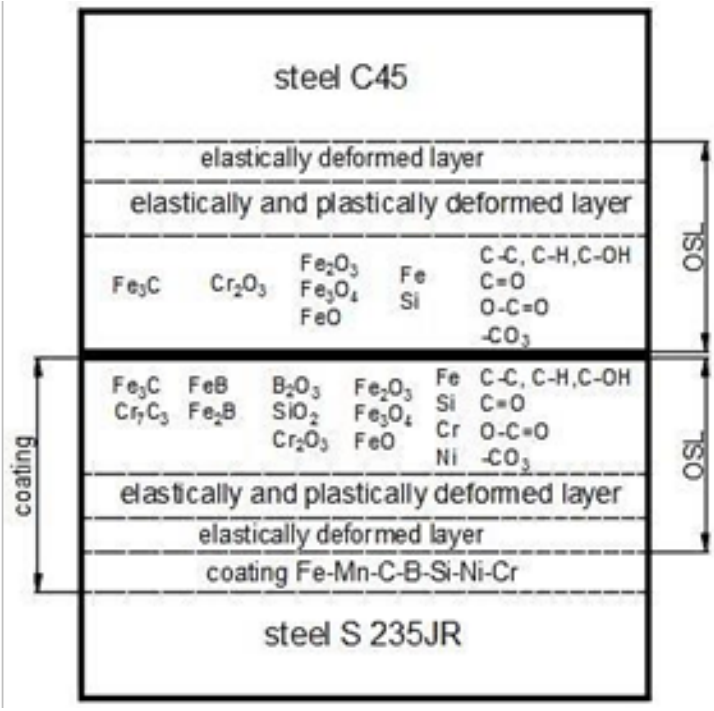

Fig. 5. Model of the surface layer for friction couple, hardfaced coating obtained from Fe-Mn-C-B-Si-NiCr alloy $-\mathrm{C} 45$ steel

inorganic compounds. The surface layer of hardfaced coatings contained oxides $\left(\mathrm{B}_{2} \mathrm{O}_{3}, \mathrm{SiO}_{2}, \mathrm{NiO}\right.$, $\mathrm{Cr}_{2} \mathrm{O}_{3}, \mathrm{FeO}, \mathrm{Fe}_{3} \mathrm{O}_{4}, \mathrm{Fe}_{2} \mathrm{O}_{3}$ ), carbides $\left(\mathrm{Fe}_{3} \mathrm{C}, \mathrm{Cr}_{7} \mathrm{C}_{3}\right)$ and borides $\left(\mathrm{FeB}, \mathrm{Fe}_{2} \mathrm{~B}\right)$. Elastically and plastically deformed zones, which were the result of unit pressures, were observed during the course of friction. Another zone was deformed elastically. The structure of the welding coating obtained of XRD (X-ray diffraction) investigation consists of alloyed austenite $\mathrm{Fe}(\mathrm{Ni}, \mathrm{Cr}$ ) (matrix phase), manganese-iron carbide $\mathrm{Fe}_{0,4} \mathrm{Mn}_{3,6} \mathrm{C}$ (reinforcing phase) and $\mathrm{Fe}_{2} \mathrm{~B}, \mathrm{Cr}_{7} \mathrm{C}_{3}$, (dispersion phase) [1113]. Boundaries between individual zones were not as clear as shown in the figure. Their thickness and presence depend on operating conditions.

\section{CONCLUSIONS}

This paper focuses on the examination of chemical composition of the friction surfaces Fe-Mn-C-B-Si-Ni-Cr hardfacing coatings. The composition of the coatings (wt.\%) is as follows: Mn-7.29; C-1.63; B-1.79; Si-2.46; Ni17.68; Cr-16.24; Fe-rest. The average mass loss of samples after tribological tests was $125 \mathrm{mg}$. The average wear coefficient was 0.59 . The surface of the coating after friction is most often of "flake-layer" composition with traces of microcutting. The chemical composition of the material's surface layer change with depth, which has been investigated by XPS analysis. At the surface and in the near-surface layer of Fe-Mn-
C-B-Si-Ni-Cr coating has been confirmed the presence of such compounds as oxides $\left(\mathrm{B}_{2} \mathrm{O}_{3}\right.$, $\left.\mathrm{SiO}_{2}, \mathrm{Cr}_{2} \mathrm{O}_{3}, \mathrm{FeO}, \mathrm{Fe}_{3} \mathrm{O}_{4}, \mathrm{Fe}_{2} \mathrm{O}_{3}\right)$, carbides $\left(\mathrm{Fe}_{3} \mathrm{C}\right.$, $\mathrm{Cr}_{7} \mathrm{C}_{3}$ ), borides $\left(\mathrm{FeB}, \mathrm{Fe}_{2} \mathrm{~B}\right)$, as well as impurities of organic carbon compounds. This compounds increases wear resistance of coatings created from Fe-Mn-C-B-Si-Ni-Cr all.

\section{REFERENCES}

1. Burakowski T., Wierzchoń T.: Inżynieria powierzchni metali, WNT, Warszawa 1995.

2. Dziedzic K., Zubrzycka-Wróbel J., Józwik J., Barszcz M., Siwak P., Chałas R.: Research on tribological properties of dental composite materials. Advances in Science and Technology Research Journal, 2016, 32, 10, 144-149.

3. Gualco A., Svoboda H., Surian E.: Study of abrasive wear resistance of Fe-based nanostructured hardfacing, Wear, 2016, 360, 14-20.

4. Józwik J., Dziedzic K., Usydus I., Raos P., Krolczyk G.M.: HS 6-5-2 steel surface layer development in carbonitoring with zeroflow method. Tehnicki Vjesnik - Technical Gazette, 2016, 5, 23, 1405-1409.

5. Krolczyk J.B., Gapinski B., Krolczyk G.M., Samardzic I., Maruda R.W., Soucek K., Javadi Y., Legutko S., Nieslony P., Stas L.: Topographic Inspection as a Method of Weld Joint Diagnostic, Tehnicki Vjesnik - Technical Gazette, 2016, 23, 1, 301-306.

6. Kumar R., Chattopadhyaya S., Hloch S., Krolczyk G., Legutko S.: Wear Characteristics and Defects analysis of Friction Stir Welded joint of Aluminium alloy 6061-T6, Maintenance and Reliability, 2016, 18, 1, 128-135.

7. Correa E.O., Alcântara N.G., Valeriano L.C., Barbedo N.D., Chaves R.R.: The effect of microstructure on abrasive wear of a Fe-Cr-C-Nb hardfacing alloy deposited by the open arc welding process, Surface \& Coatings Technology, 2015, 276, 479-484.

8. Feldshtein E., Józwik J., Legutko S.: The influence of the conditions of emulsion mist formation on the surface roughness of AISI 1045 steel after finish turning. Advances in Science and Technology Research Journal, 2016, 10, 30, 144-149.

9. Napiórkowski J., Pękalski, G. Kołakowski K.: Badanie struktur i zużywania powłok napawanych w glebowej masie ściernej, Tribologia, tarcie, zużycie, smarowanie, 2012, 3, 111-117.

10. Liu H., Song Z., Cao Q., Chen S., Meng Q.: Microstructure and properties of $\mathrm{Fe}-\mathrm{Cr}-\mathrm{C}$ hardfacing alloys reinforced with $\mathrm{TiC}-\mathrm{NbC}$, Journal of Iron and Steel Research, 2016, 23, 3, 276-280.

11. Pashechko M., Dziedzic K., Barszcz M.: Study of the structure and properties of wear-resistant eutectic Fe-Mn-C-B-Si-Ni-Cr coatings, Powder Metallurgy and Metal Ceramics, 2013, 7-8, 52, 469-476. 
12. Pashechko M., Dziedzic K., Dziubińska A., Barszcz M.: Assessment of the tribological properties of hardfacing welding alloy $\mathrm{Fe}-\mathrm{Mn}-\mathrm{C}-\mathrm{B}-\mathrm{Si}-\mathrm{Ni}-\mathrm{Cr}$ in dry friction conditions, Tribologia, 2016, 2, 101-110.

13. Pashechko M., Lenik K.: Segregation of atoms of the eutectic alloys Fe-Mn-C-B-Si-Ni-Cr at friction wear, Wear, 2009, 267, 1301-1304.

14. Yüksel N., Sahin S.: Wear behavior-hardness-microstructure relation of $\mathrm{Fe}-\mathrm{Cr}-\mathrm{C}$ and Fe-Cr-C-B based hardfacing alloys, Materials and Design, 2014, 58, 491-498.

15. Glowacz A., Glowacz Z.: Diagnosis of the threephase induction motor using thermal imaging, Infrared Physics \& Technology, 2017, 81, 7-16.

16. Glowacz A., Glowacz Z.: Diagnostics of stator faults of the single-phase induction motor using thermal images, MoASoS and selected classifiers, Measurement, 2016, 93, 86-93.

17. Nieslony P., Krolczyk G.M., Zak K., Maruda R.W., Legutko S.: Comparative assessment of the mechanical and electromagnetic surfaces of explosively clad Ti-steel plates after drilling process. Precision Engineering, 2017, 47, 104 -110.

18. Novák M., Náprstková N., Józwik J.: Analysis of the surface profile and its material share during the grinding Inconel 718 alloy, 2015, 9, 26, 41-48.
19. Riviere J.C., Myhra S.: Handbook of surface and interface analysis, CRC Taylor \& Francis Group, Boca Raton 2009.

20. Burakowski T., Marczak R.: Eksploatacyjna warstwa wierzchnia i jej badanie, Zagadnienia Eksploatacji Maszyn, 1995, 3, 103, 327-337.

21. Marczak R.: Warstwa wierzchnia, współczesny stan wiedzy i kierunki przyszłych badań, Tribologia, 2002, 3, 939-955.

22. Kusiak C.: Modele oddziaływania pomiędzy powierzchniami ciał stałych podczas tarcia ślizgowego, Polska Tribologia 2000, Teoria i praktyka, Prace Naukowe, 2000, 1, 17, 108-114.

23. Szczerek M., Wiśniewski M.: Tribologia i Tribotechnika, Wyd. i Zakład Poligrafii Instytutu Technologii Eksploatacji, Radom 2000.

24. Kurzydłowski K., Lewandowska M.: Materiały inżynierskie konstrukcyjne i funkcjonalne, PWN, Warszawa 2010.

25. Mandrino D., Podgornik B.: XPS investigations of tribofilms formed on CrN coatings, Applied Surface Science, 2017, 396, 554-559.

26. Beamson G., Briggs D.: High Resolution XPS of Organic Polymers - The Scienta ESCA 300 Database Wiley Interscience, 1992. 